\title{
Impacts of dugong foraging on seagrass habitats: observational and experimental evidence for cultivation grazing
}

\author{
Anthony Preen* \\ Department of Tropical Environment Studies and Geography, James Cook University, Queensland 4811, Australia
}

\begin{abstract}
In Moreton Bay, Australia, dugongs (Dugong dugon) often graze in large herds at the same location for weeks to months. Such grazing reduced seagrass shoot density by 65 to $95 \%$, aboveground biomass by 73 to $96 \%$ and belowground biomass by 31 to $71 \%$ at 3 sites ranging in size from 2 to $75 \mathrm{ha}$. Following even the most intense and sustained grazing, the space between surviving tufts of seagrass remains small $\left(<1 \mathrm{~m}^{2}\right)$ and recovery is usually rapid (months). In this regard, intensive grazing differs from disturbances caused by storms, sedimentation or disease. However, recovery of seagrass meadows can be suppressed by low levels of sustained grazing pressure. The species composition of seagrass meadows can be altered by intensive grazing, which favours rapidly growing, early pioneer species, such as Halophila ovalis, at the expense of slower growing but dominant species such as Zostera capricorni. In Moreton Bay, H. ovalis is the most nutritious (high nitrogen, low fibre) and the most preferred seagrass grazed by dugongs. Z. Capricorni is the least preferred species. By preventing the expansion of $Z$. capricorni and increasing the abundance of $H$. ovalis, this grazing system, termed cultivation grazing, can improve the quality of the dugong's diet.
\end{abstract}

KEY WORDS: Cultivation grazing $\cdot$ Seagrasses $\cdot$ Dugongs

\section{INTRODUCTION}

Dugongs (Dugong dugon) are large marine mammalian grazers of the tropical Indo-west Pacific region, where they feed primarily on near-shore seagrasses (Lipkin 1975, Johnstone \& Hudson 1981, Marsh et al. 1982). Nutritionally, many herbivores are constrained by the limited abundance of dietary nitrogen (Sinclair 1977, Mattson 1980, White 1993), and seagrasses have low levels of nitrogen compared with terrestrial grasses (Birch 1975, Duarte 1990, Lanyon 1991). Dugongs are further constrained by their rudimentary dentition, which leaves them ill-equipped to process fibrous plant material (Lanyon 1991). In Moreton Bay, at the southern limit of their range in eastern Australia, dugongs counter these constraints by feeding on softbodied invertebrates (Preen 1995) and by feeding selectively to maximise their intake of preferred (high

-E-mail: anthony.preen@jcu.edu.au nitrogen, low fibre) seagrasses (Preen 1993). They feed primarily in communities dominated by their preferred early pioneer species, and on patches of such species within other communities (Preen 1993). During most of the year, dugongs avoid grazing communities dominated by the relatively fibrous Zostera capricorni (broad-leafed morph), which is the dominant species in the area (Preen 1993). However, where $Z$. capricorni is intermingled with more preferred species, it is consumed (Preen 1993). Dugongs are generally prevented from feeding selectively at the individual plant level by their wide muzzles ( $22 \mathrm{~cm}$; Spain \& Heinsohn 1975) and by their habit of cropping along serpentine feeding paths, known as feeding trails (see Fig. 1b).

In Moreton Bay, where there is no significant grazing of seagrasses by fish, birds or invertebrates, and where there appears to be relatively low grazing pressure from green turtles Chelonia mydas, dugongs are the main consumers of seagrasses. They usually feed in large herds (median herd size 140), which often graze the same location for periods of up to a month or more 
(Preen 1993). Such grazing may have a profound impact on the seagrasses. In this paper, I examine the ecological effects of this grazing on seagrass communities by documenting the grazing and recovery of heavily cropped areas, and by describing a manipulative experiment that simulated dugong grazing in a mixed seagrass community. I conclude that cultivation grazing maximises the abundance of seagrass species that are preferred by dugongs, at the expense of less preferred species. This grazing pattern appears to be a deliberate strategy to improve the quality of the dugong's diet.

\section{METHODS}

Study area. The study area was located in the east of Moreton Bay, a $1400 \mathrm{~km}^{2}$, wedge-shaped embayment located in subtropical Queensland, on the east Australian coast $\left(27.5^{\circ} \mathrm{S}, 153.3^{\circ} \mathrm{E}\right)$. Moreton Bay is approximately $100 \mathrm{~km}$ long and ranges in width from $1 \mathrm{~km}$ in the south to $31 \mathrm{~km}$ in the north. The study area encompassed a quartz sand delta that fans westwards between Moreton and North Stradbroke Islands, which form the seaward side of the bay. The study area contains $110 \mathrm{~km}^{2}$ of predominantly subtidal seagrass meadows (to a maximum depth of $7 \mathrm{~m}$ ) and supports approximately 600 dugongs (Preen 1993).

Grazing and recovery of feeding areas. Grazing sites were identified during regular, standardised aerial surveys (detailed in Preen 1993), or during boatbased encounters with dugong herds. The most reliable counts of grazing dugongs were made during the aerial surveys. It was difficult to locate and sample feeding areas before they had been substantially disturbed because the dugongs' mobility made it impossible to predict their movements between aerial surveys (approximately $3 \mathrm{wk}$ apart) and the large size of many feeding herds meant that substantial disturbance could occur quickly. Consequently, I speculatively sampled many sites to assess the abundance of seagrasses before significant grazing occurred. As I did not expect many of these sites to be substantially grazed, it was not practical to sample them exhaustively. I measured the abundance of seagrass prior to, and following, intensive grazing at 3 areas, and I monitored the recovery of 2 of these. I also followed the succession of species at a fourth area that apparently had been grazed previously. The size of sampling quadrats varied, depending on the density and uniformity of the seagrasses. The size of grazed areas was measured from digitised vertical aerial photographs that were used to map the seagrass communities.

Area 1: This area had a uniform cover of the following seagrasses (in decreasing order of abundance):
Halophila ovalis, Halophila spinulosa, Halodule uninervis (broad-leafed morph; $>1 \mathrm{~mm}$ wide) and Zostera capricorni (broad-leafed morph; $>1 \mathrm{~mm}$ wide). Pregrazing seagrass abundance was measured on the day grazing commenced ( 9 January 1990) by counting shoots in 18 quadrats (each $0.008 \mathrm{~m}^{2}$ ) haphazardly located around the dugongs' first feeding trails. Postgrazing seagrass abundance was assessed $12 \mathrm{~d}$ later using 110 haphazardly located quadrats (each $\left.0.005 \mathrm{~m}^{2}\right)$.

Area 2: This area was characterised by 1 to $20 \mathrm{~m}$ diameter patches of Zostera capricorni (broad) scattered through a matrix of Halodule uninervis (broad). Grazing was restricted almost exclusively to the $H$. uninervis. Grazing commenced in mid-August 1989 , and generally extended northwards until the end of November. Pregrazing seagrass abundance (shoot density and biomass) of $H$. uninervis was determined on 22 November from 10 quadrats $\left(0.005 \mathrm{~m}^{2}\right)$ haphazardly located in ungrazed clumps of seagrass adjacent to feeding trails. Postgrazing recovery was monitored over 5 mo using 3 permanent, $20 \mathrm{~m}$ transects located 200 to $400 \mathrm{~m}$ apart in the $H$. uninervis. The seagrass was sampled in 10 quadrats $\left(0.05 \mathrm{~m}^{2}\right)$ along each transect at 2 to 3 mo intervals (22 November 1989, 21 January 1990 and 1 May 1990). The direction of sampling along the transects, and the side of the transect sampled were varied to ensure that quadrats sampled different locations in each sampling period. Quadrats were excavated to a depth of 5 to $10 \mathrm{~cm}$ and processed in the laboratory to determine shoot density and dryweight biomass.

Area 3: This area encompassed an almost monospecific stand of Halophila ovalis (Fig. 1a), with a trace of Halodule uninervis (narrow-leafed morph; $\leq 1 \mathrm{~mm}$ wide). Aerial and boat-based surveys established that grazing commenced on or about 6 March 1989 and continued until 23 March. Pregrazing abundance of seagrass was assessed on 8 March by counting shoots in 17 quadrats $\left(0.023 \mathrm{~m}^{2}\right)$ haphazardly located around some recent feeding trails (Fig. 1b). The recovery of the seagrass community was monitored for over 9 mo using $3 \times 20 \mathrm{~m}$ transects, like those used at Area 2, that were $150 \mathrm{~m}$ apart. Ten quadrats $\left(0.05 \mathrm{~m}^{2}\right)$ were sampled along each transect on 6 occasions between 23 March 1989 and 7 January 1990. Quadrats were excavated and processed in the laboratory. The area was intensively grazed a second time during the period of monitoring, on 4 September 1989. These 2 grazing incidents at Area 3 are referred to as 3-1 and 3-2.

It was not feasible to establish specific control sites adjacent to each grazing area, due to the likelihood that grazing would eventually extend into those sites. To locate control sites far from the grazing areas would be of questionable validity due to changes in species 
composition, water depth and other variables. I used an alternative approach to gain an indication of the recovery of the grazed areas to their predisturbance states. I determined the seasonal growth patterns of the seagrasses by monitoring 9 sites throughout the study area at intervals of 3 mo for 2 yr $\left(25 \times 0.005 \mathrm{~m}^{2}\right.$ quadrats site ${ }^{-1}$ sampling period ${ }^{-1}$ ). As these sites were not protected with exclosures, they may have experienced some low-intensity grazing on some occasions during the $2 \mathrm{yr}$. If they did, it was not obvious, and it was unlikely to have affected the seasonal growth patterns. Between seasons of minimum and maximum abundance, the shoot density, above- and belowground biomass varied by factors of $1.2,2.4$ and 1.6 , respectively, for Halodule uninervis and by $2.2,1.9$ and 2.7 for Halophila ovalis (Preen 1993). I used the seasonal growth data to develop correction factors which I applied to the pregrazing abundance of seagrass at grazing Areas 2 and 3 to predict how those seagrass meadows may have changed through the seasons, had no grazing occurred. Comparisons between the abundance of seagrass at the grazed areas and the predicted changes provide an indication of the areas' recovery.

Area 4: When first sampled, this site had a low biomass cover of Halophila ovalis and Halophila spinulosa. The sediments, however, contained a large amount of dead rhizome of Zostera capricorni (broad). Based on the decomposition rate of Zostera rhizomes (Kenworthy \& Thayer 1984, Preen 1993) it is apparent. that $Z$. capricorni was a conspicuous species at this site 3 to 6 mo prior to sampling. The Maroom Bank, on which this site was located, is dominated by $H$. spinulosa and $H$. ovalis, with $Z$. capricorni intermingled in patches. As this area was a favoured dugong grazing area during this study (Preen 1993), it was likely that the low seagrass biomass and absence of $Z$. capricorni at Area 4 was due to intensive grazing. Hence, the seagrasses at this site were monitored for the subsequent 2 yr. At 3 mo intervals, from July 1988 to April 1990, 25 quadrats (each $0.05 \mathrm{~m}^{2}$ ) were sampled from along a permanent $50 \mathrm{~m}$ transect. Quadrats were placed at $2 \mathrm{~m}$ intervals along the transect, which was sampled from different directions and on different sides during each sampling period to prevent resampling of the same quadrat sites. Quadrats were excavated and processed in the laboratory to determine shoot density and biomass.

Exclosure experiment. A manipulative experiment that simulated dugong grazing was established in the seagrasses on the Maroom Bank to test the following hypotheses: (1) that the expansion of Zostera capricorni on the Maroom Bank is not restricted by a physiological limitation; (2) that low-intensity grazing by dugongs does not change the relative abundance of species in the seagrass meadow; (3) that intense grazing by dugongs does not retard the expansion of $Z$. capricorni or encourage the dominance of Halophila ovalis.

Exclosures were used to protect plots of the following 3 simulated grazing treatments from the confounding influences of uncontrolled grazing by dugongs: (1) No-grazing: exclosure only. The seagrass was not disturbed. (2) Low-intensity grazing: 3 simulated feeding trails that were $3 \mathrm{~m}$ long, $18 \mathrm{~cm}$ wide, approximately $6 \mathrm{~cm}$ deep and $1 \mathrm{~m}$ apart. The 'trails' were excavated using a garden spade and closely resembled natural feeding trails in terms of shoot density and patchiness. (3) High-intensity grazing: intensive grazing was simulated by removing most of the seagrass from a $9 \mathrm{~m}^{2}$ area. Shoots and rhizomes were removed by hand until the shoot density and patchiness of the seagrasses resembled a heavily grazed meadow (90 to $95 \%$ seagrass removal; see below).

A plot of each grazing treatment was established at each of 3 replicate, subtidal sites. The sites were approximately $2.5 \mathrm{~m}$ below mean sea level and were at least $2 \mathrm{~km}$ apart. A fourth site was used to examine the effect of the exclosures on seagrass abundance; seagrasses were monitored within an exclosure and within an equivalent unprotected plot (no exclosure) about $2 \mathrm{~m}$ away. The control site was not located with the treatment sites because of the likelihood that unprotected plots would be grazed. Instead, the control site was located in the same seagrass community in an area not used by dugongs (presumably because of greater boat traffic). The limited availability of this seagrass community in areas not used by dugongs prevented the replication of exclosure-control sites.

The experimental seagrass community contained approximately equal proportions of Zostera capricorni (broad), Halophila spinulosa and Halophila ovalis. This mix was chosen as it was similar to a previously studied feeding site where $Z$. capricorni was grazed when interspersed with $H$. spinulosa and $H$. ovalis. $Z$. capricorni was usually avoided when it occurred at higher densities (Preen 1993).

The $3 \times 3 \mathrm{~m}$ exclosures consisted of wooden stakes projecting $25 \mathrm{~cm}$ above the sediment and linked by light ( $4 \mathrm{~mm}$ ) rope around the perimeter and across the top. Hence, they formed a $25 \mathrm{~cm}$ high fence around the enclosed area with an open net $\left(1 \mathrm{~m}^{2}\right.$ mesh) over the top. They were designed to deter dugong and turtle grazing without affecting light and water-flow regimes. The exclosures would not stop a determined dugong from feeding through the top mesh, but it was hoped that the fence would interrupt a dugong's feeding motion and so prevent feeding trails from crossing the experimental areas. The use of the area by boats precluded the construction of higher fences that could 

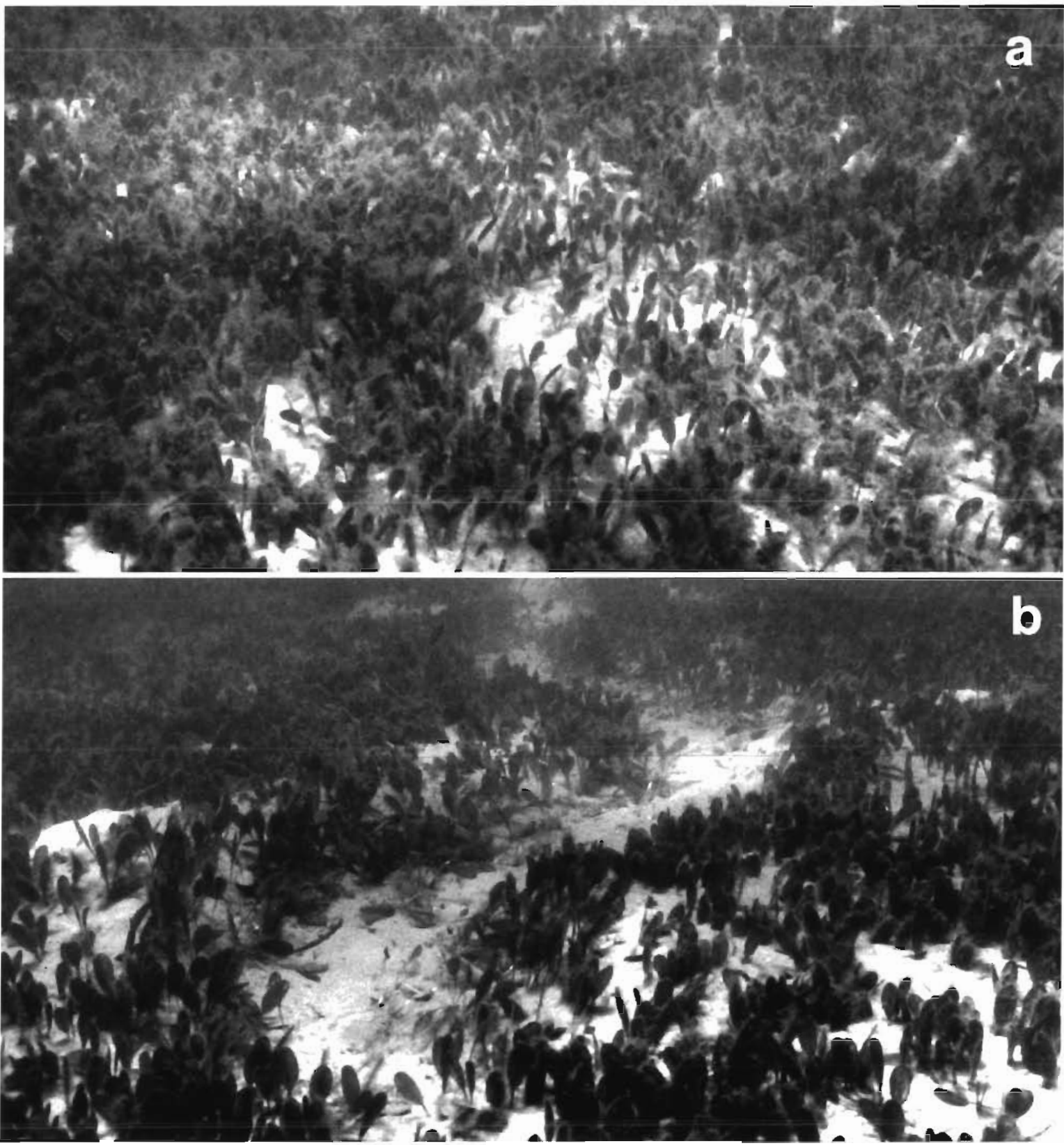

Fig. 1. (Above and facing page.) Impact of dugong grazing at Area 3-1. (a) Ungrazed tract of Halophila ovalis. (b) A single feeding trail at the same location. (c) Same location after 3 h grazing by about 70 dugongs. As many as 459 dugongs grazed this area for about $17 \mathrm{~d}$, reducing the density of seagrass shoots by $95 \%$ over an area of 41 ha. Seagrass leaves are approximately $35 \mathrm{~mm}$ tall

have excluded herbivores. The unprotected site was marked with 4 corner pegs that projected $1 \mathrm{~cm}$ above the sediment.

To minimise the influence of very small-scale patchiness in the seagrasses, the abundance of seagrass was monitored over an area of $4 \mathrm{~m}^{2}$ within each $9 \mathrm{~m}^{2}$ exclosure. These core areas were surrounded by a $0.5 \mathrm{~m}$ wide buffer, to avoid any edge effect. The ropes of the exclosures were cleaned of drift algae at intervals of 1 to $4 \mathrm{wk}$. 


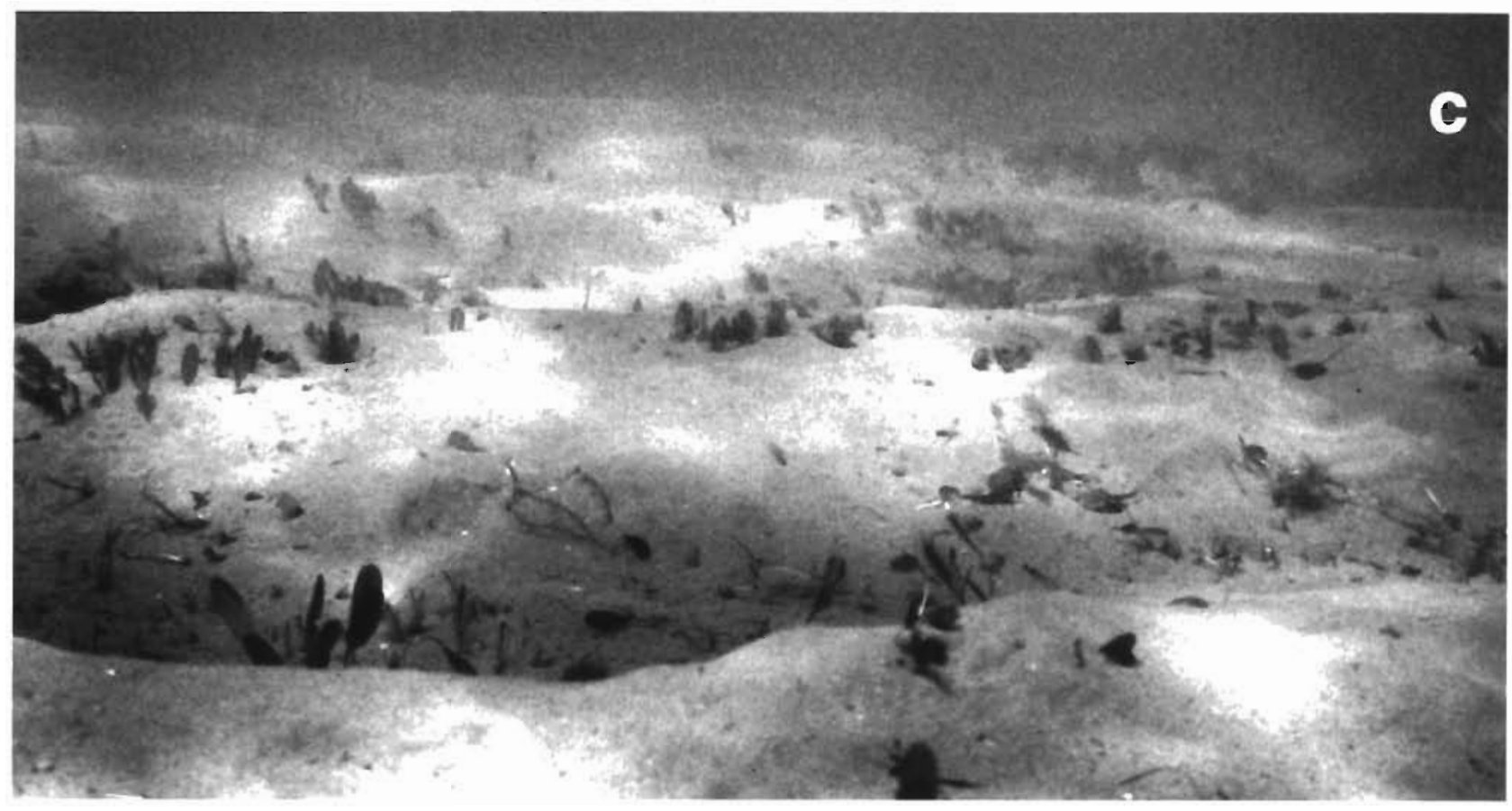

Seagrass shoots were counted in $0.023 \mathrm{~m}^{2}$ quadrats systematically located in each exclosure. Thirty quadrats ( 6 quadrats along each of 5 transects) were monitored within each exclosure (and the unprotected plot), except in the low-intensity grazing treatment. In that treatment, 18 quadrats were monitored: 6 quadrats along each of the 3 simulated feeding trails. A pilot study indicated that at least 14 quadrats would be required to detect a $50 \%$ change in abundance. The position of each quadrat was rigidly controlled so repeat counts censused the same locations ( \pm 2 to $5 \mathrm{~cm}$ ). The abundance of seagrasses in the low-and high-intensity treatments was measured immediately prior to the seagrass manipulations. The abundance of seagrasses at all sites was then monitored on 4 occasions (approximately $100 \mathrm{~d}$ apart) between late June 1989 and early May 1990.

Statistical analysis: Shoot density [transformed by $\log _{10}$ (shoot density +1 ) to equalise variances over the wide range of shoot densities] was analysed using a mixed-model analysis of variance. The response variable was the mean shoot density for each plot at each time ( $n=36$ ). Factors included in the model were species, grazing level, time and site. Site was taken as a random factor, while species, grazing level and time were fixed. The mixed model is thus a univariate repeated-measures model with 2 repeated factors (species and time). This model assumes a constant covariance structure over species, time and the species by time interaction. This was tested with the sphericity test (SAS Institute Inc. 1991) for species and time, but it was not possible to test the interaction due to the limited degrees of freedom. The model also assumes that there was no interaction between site and grazing treatment. This is a reasonable assumption given that the sites were carefully selected for their similarity of species composition, shoot density, sediment type and water depth. Residual plots were used to assess the data for homoscedasticity of variances.

\section{RESULTS}

\section{Grazing and recovery of feeding areas}

\section{Number of grazing dugongs}

Like other large herbivores (Leuthold 1977), dugongs appear to spend most of their time grazing. Hence, the density of dugongs on a seagrass meadow during the day provides an indication of the intensity of grazing at that location. The number of dugongs that grazed Area 1 is unknown, although I estimated (from a boat) that approximately 50 dugongs were feeding at the site when it was first sampled. The dugongs had apparently left the area when it was resampled $12 \mathrm{~d}$ later. Between 60 and 219 dugongs were seen feeding in Area 2 on 8 consecutive aerial surveys over 4 mo (Fig. 2aj. Most grazing around the monitoring transects occurred during the first month. During this period the area was searched 3 times from the air and 3 times from a boat. Herds of 153, 187 and 219 dugongs were 


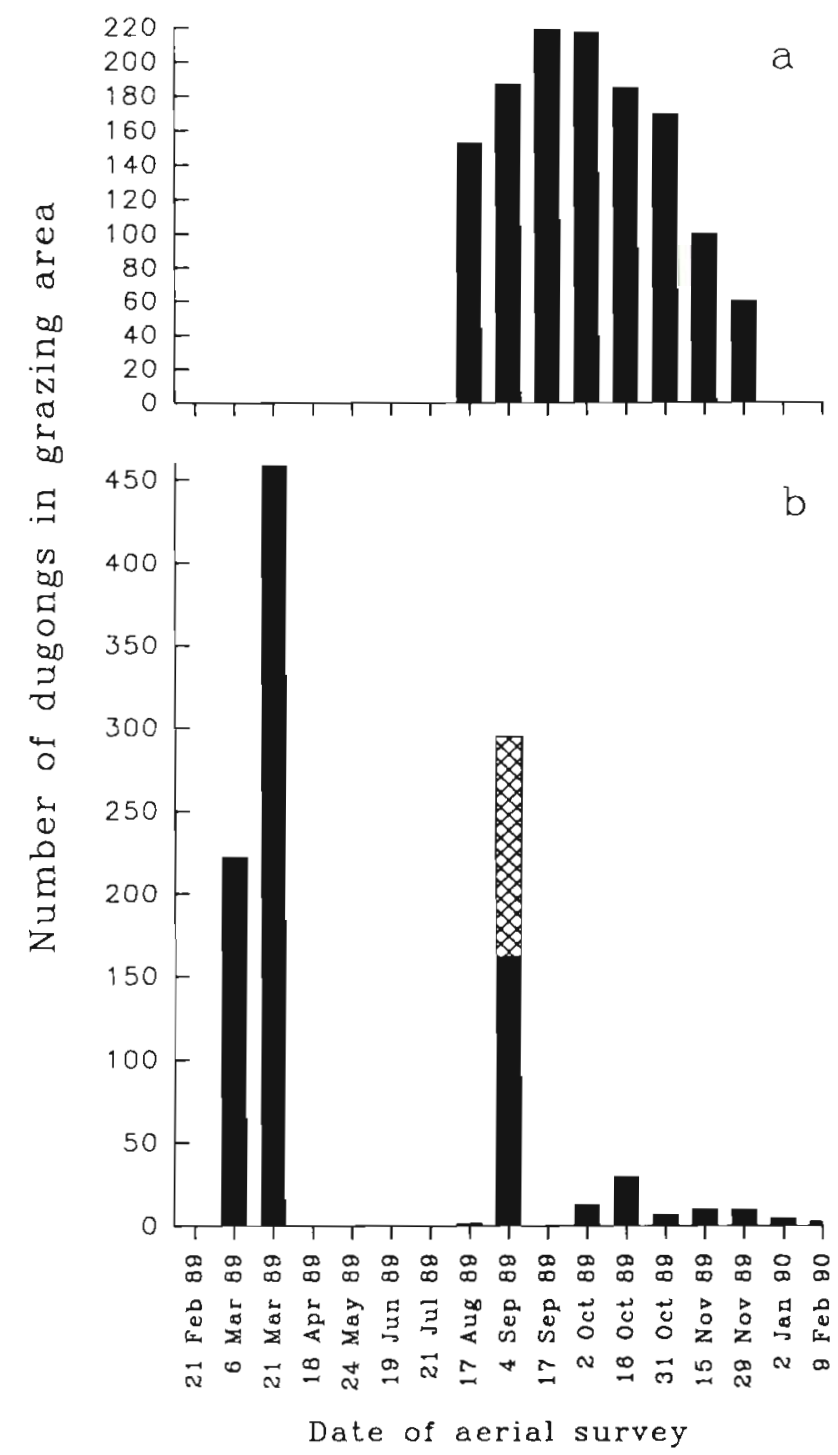

counted during aerial surveys (Fig. 2a), while an estimated 100 to 150 dugongs were present in the area during each boat survey. At Area 3 the grazing incidents were brief, but intense. An average of only 1 dugong was seen in this area during 12 aerial surveys spanning 8 mo before the first recorded grazing (3-1), which involved up to 459 dugongs and took place over about 17 d (Fig. 2b). Boat and aerial surveys confirmed that the area was not used by dugongs for the next $5 \mathrm{mo}$, when it was briefly grazed again. This second grazing incident (3-2) occurred in less than $17 \mathrm{~d}$ (the area was ungrazed when observed during an aerial survey on 17 August 1989, but it had been thoroughly grazed by 2 September, when aerial photographs were taken for seagrass mapping). A herd of 162 dugongs was seen on the area on 4 September (Fig. 2b), although the pattern of feeding trails apparent from the air indicated that another herd of 133 dugongs, located $<1 \mathrm{~km}$ away, had probably grazed the site also. The area was subsequently grazed at a low level for the rest of the monitoring period (Fig. 2b).

\section{Amount of seagrass removed}

At Area 2, shoot density, aboveground biomass and belowground biomass were reduced by 65,73 and $31 \%$ respectively over 3.5 mo (Table 1 , Fig. 3 ). Grazing

Fig. 2. Number of dugongs counted in (a) Area 2 and (b) Area 3 during aerial surveys. Shading indicates a second herd, of 133 dugongs, adjacent to and suspected of also grazing Area 3 on or before 4 September 1989. Insignificant numbers of dugongs were seen in these areas during 11 surveys preceding those graphed

Table 1. Abundance of Halophila ovalis, Halophila spinulosa, Halodule uninervis and Zostera capricorni at feeding areas before and after they were intensively grazed by dugongs, and the percentage of seagrass removed. 3-1 and 3-2 refer to the first and second grazing of Area 3. Biomasses are dry weights

\begin{tabular}{|c|c|c|c|c|c|}
\hline & \multirow[t]{2}{*}{ Area } & \multirow[t]{2}{*}{ Species } & \multicolumn{2}{|c|}{ Seagrass abundance (mean \pm SE) } & \multirow[t]{2}{*}{ Reduction (\%) } \\
\hline & & & Before grazing & After grazing & \\
\hline \multirow[t]{8}{*}{ Shoot density (shoots $\mathrm{m}^{-2}$ ) } & Area 1 & All & $1587.3 \pm 116.7$ & $213.3 \pm 37.2$ & 86.6 \\
\hline & & H. ovalis & $980.4 \pm 103.3$ & $115.3 \pm 20.6$ & 88.2 \\
\hline & & H. spinulosa & $504.2 \pm 74.1$ & $76.9 \pm 21.9$ & 85.8 \\
\hline & & H. uninervis & $66.7 \pm 32.5$ & $3.8 \pm 2.7$ & 94.2 \\
\hline & & Z. capricorni & 0.0 & $17.3 \pm 3.6$ & \\
\hline & Area 2 & H. uninervis & $2875.3 \pm 678.3$ & $1016.4 \pm 157.3$ & 64.7 \\
\hline & Area 3-1 & H. ovalis & $2839.2 \pm 133.5$ & $155.9 \pm 30.6$ & 94.5 \\
\hline & Area $3-2$ & H. ovalis & $1445.7 \pm 110.4$ & $118.3 \pm 22.0$ & 91.8 \\
\hline \multirow[t]{2}{*}{ Aboveground biomass $\left(\mathrm{g} \mathrm{m}^{-2}\right)$} & Area 2 & H. uninervis & $16.9 \pm 4.7$ & $4.6 \pm 0.8$ & 73.0 \\
\hline & Area $3-2$ & H. ovalis & $22.6 \pm 2.2$ & $1.0 \pm 0.2$ & 95.8 \\
\hline \multirow[t]{2}{*}{ Belowground biomass $\left(\mathrm{g} \mathrm{m}^{-2}\right)$} & Area 2 & H. uninervis & $137.6 \pm 13.9$ & $94.8 \pm 11.5$ & 31.1 \\
\hline & Area 3-2 & H. ovalis & $27.9 \pm 2.5$ & $8.0 \pm 1.1$ & 71.3 \\
\hline
\end{tabular}




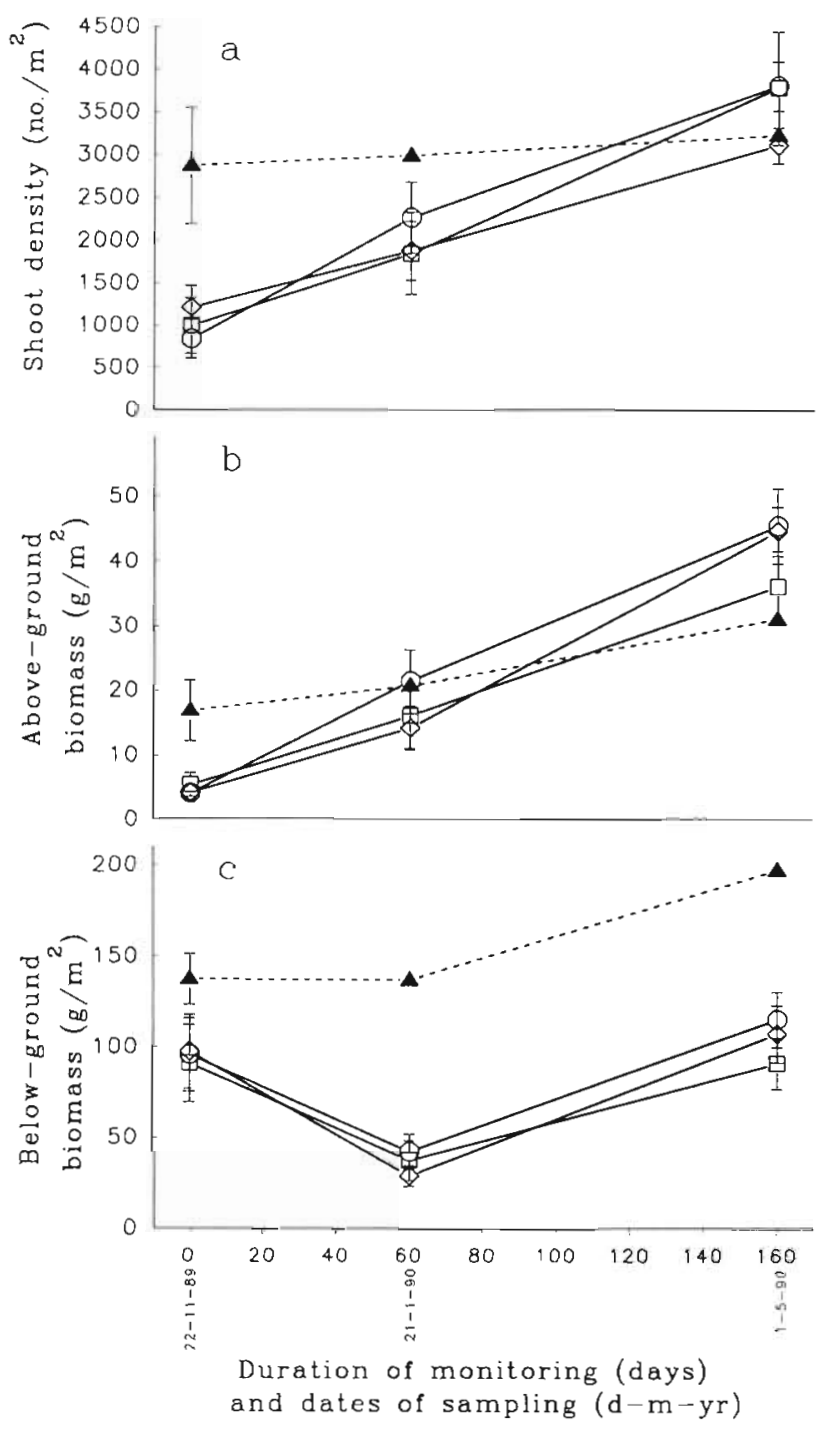

Fig. 3. Halodule uninervis. Response to intensive grazing by dugongs at Area 2. (a) Shoot density. (b) Aboveground biomass. (c) Belowground biomass. $(\square, 0, \diamond)$ Seagrass abundance along 3 transects ( \pm SE). Abundance of seagrass prior to grazing (4) has been seasonally adjusted to show the expected changes in the absence of grazing

was more intensive at Areas 1, 3-1 and 3-2, where, respectively, the number of seagrass shoots was reduced by $87 \%$ in $12 \mathrm{~d}, 95 \%$ in about $17 \mathrm{~d}$, and $92 \%$ in less than $17 \mathrm{~d}$ (Table 1, Fig. 4). At Area 3-2 the biomass of seagrass was reduced by 96 and $71 \%$ for the above- and belowground components respectively (Table 1).

These reductions represent the removal of large amounts of seagrass because large areas were affected: 2, 75 and 41 ha at Areas 1, 2 and 3, respectively. Based on the biomass of seagrass at Area 3 before and after the second grazing incident (Table 1),
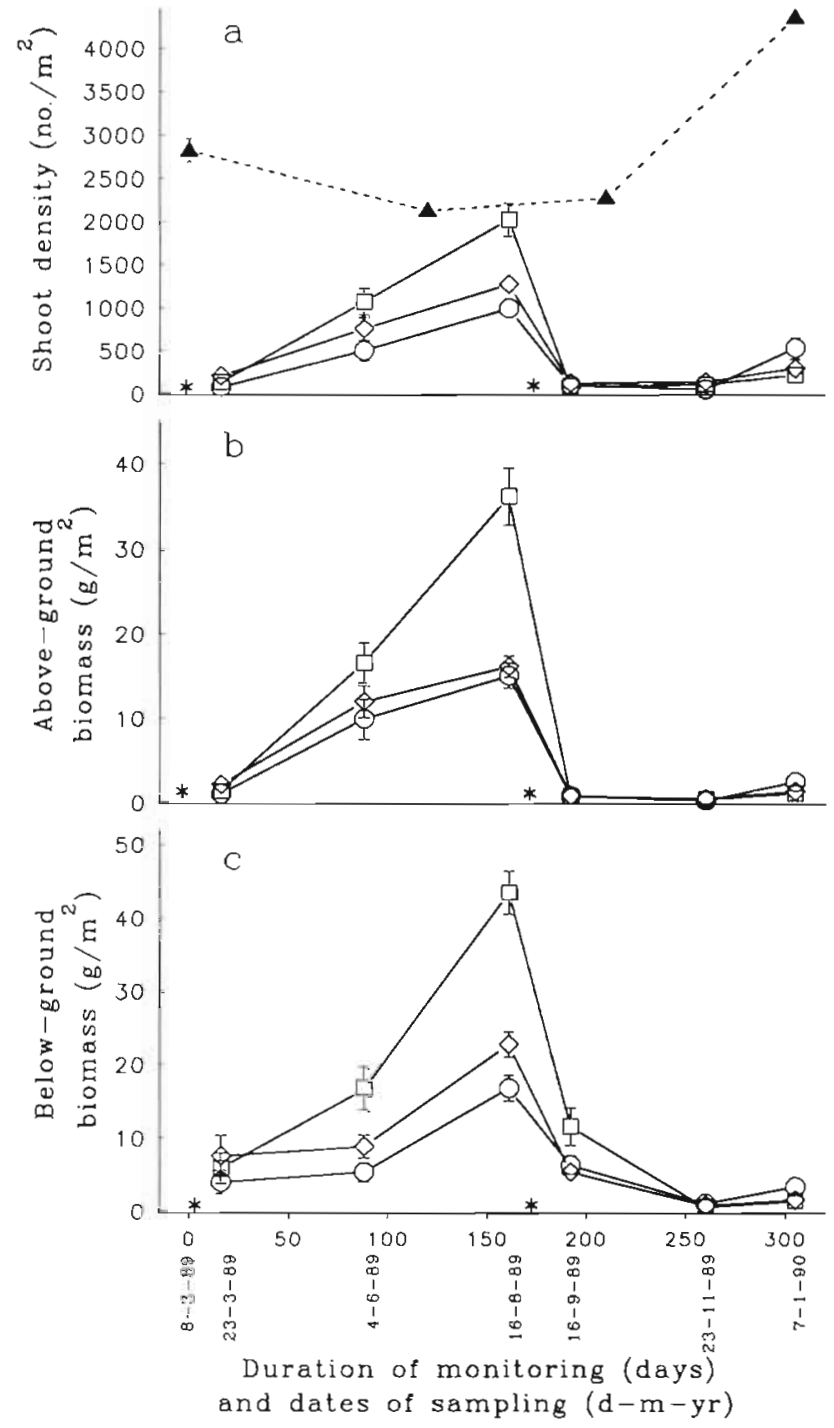

Fig. 4. Halophila ovalis. Response to intensive grazing by dugongs at Area 3. (a) Shoot density. (b) Above-ground biomass. (c) Below-ground biomass. $(\square, 0, \diamond)$ Seagrass abundance along 3 transects $( \pm S E$ ). Abundance of seagrass prior to grazing ( $\Delta$ ) has been seasonally adjusted to show the expected changes in the absence of grazing. (*) Timing of the first and second grazing incidents

and assuming that the 3 sampling transects were representative of the 41 ha area (as suggested by subsequent mapping; Preen 1993), I estimate that the dugongs consumed over $151000 \mathrm{~kg}$ wet weight of seagrass in under $17 \mathrm{~d}$.

Immediately following the second grazing incident at Area 3, the aboveground biomass had been reduced to $1.0 \mathrm{~g} \mathrm{~m}^{-2}$ (SE 0.2 ) and the belowground biomass to $8.0 \mathrm{~g} \mathrm{~m}^{-2}$ (SE 1.1; Table 1, Fig. 4). Despite the greatly diminished biomass of seagrass, dugongs continued to graze the area at a low intensity (Fig. 2b). By the end of November, when the seagrasses 
were next sampled, this continued, low-intensity grazing had reduced the biomass of rhizomes and roots to $1.03 \mathrm{~g} \mathrm{~m}^{-2}$ (SE 0.19; Fig. 4) Compared with the level prior to the second grazing, this was a net reduction of $96.3 \%$. The low-intensity grazing had little impact on the density or biomass of shoots [further reducing aboveground biomass to $0.56 \mathrm{~g} \mathrm{~m}^{-2}$ (SE 0.11) and changing shoot density from 118.26 shoots $\mathrm{m}^{-2}$ (SE 22.02) to 112.41 shoots $\mathrm{m}^{-2}$ (SE 23.32); Fig. 4].

\section{Recovery}

At Area 2, the shoot density and aboveground biomass of Halodule uninervis recovered to seasonally

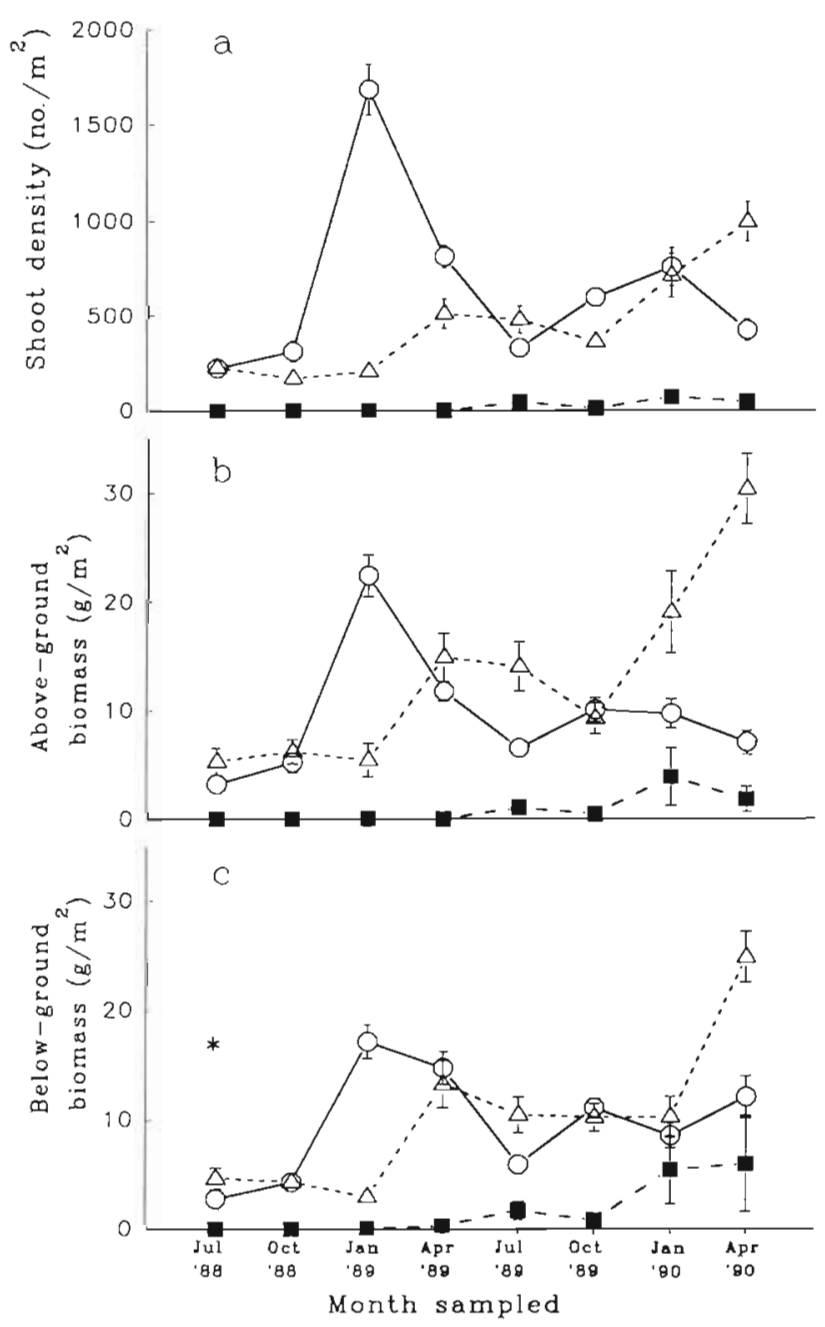

Fig. 5. Abundance (mean $\pm \mathrm{SE}$ ) of (O) Halophila ovalis, $(\Delta)$ Halophila spinulosa and ( $\square$ ) Zostera capricorni at Area 4 over 21 mo. (a) Shoot density. (b) Aboveground biomass. (c) Belowground biomass. (*) Abundance of dead rhizomes of $Z$. capricorni adjusted pregrazing levels within $160 \mathrm{~d}$, which spanned the summer and autumn growing season (Fig. 3a, b). The grazing may have stimulated an increase in the abundance of shoots above the level that would have been achieved in the absence of grazing (Fig. 3a). The belowground biomass, however, was much slower to recover, largely because it continued to decline after the grazing had finished (Fig 3c). This response may have resulted from the eventual death of some small sections of rhizome created by the high density of intersecting feeding trails

At Area 3, the initial recovery of the seagrass was rapid, despite the severity of the grazing (Fig. 4). Approximately $150 \mathrm{~d}$ after the first grazing, the average density of Halophila ovalis had increased 9-fold, from a postgrazing density of 156 (SE 31) to 1446 (SE 110) shoots $\mathrm{m}^{-2}$. This represented a recovery to more than half $(65 \%)$ of its seasonally adjusted, pregrazing abundance ( 2215 shoots $\mathrm{m}^{-2}$; Fig. 4). This recovery was achieved during autumn and winter, when the growth rate of $H$. ovalis is at its lowest (Preen 1993).

The second grazing event at Area 3 (3-2) removed $92 \%$ of the shoots of the recovering meadow of Halophila ovalis (Table 1). Despite a favourable growing period (spring-summer), continued low-level grazing by dugongs was enough to prevent any recovery within the next $100 \mathrm{~d}$ (Fig. 4).

The amount of seagrass at Area 4 increased during the 21 mo monitoring period. No major grazing events occurred during this time, although occasional lowlevel grazing was probably common. The relative and absolute abundance of Halophila ovalis increased rapidly soon after the monitoring commenced, and this species dominated the meadow for 6 mo (Fig. 5). $H$. ovalis was codominant with Halophila spinulosa for the next $6 \mathrm{mo}$, when $H$. spinulosa became the dominant species. Live Zostera capricorni first appeared at the site 9 mo after the monitoring commenced, presumably as a result of seed germination, and its abundance steadily increased through time (Fig. 5).

\section{Exclosure experiment}

\section{Effect of exclosures}

The exclosure had no effect on the abundance of Zostera capricorni or Halophila spinulosa (Fig. 6). The exclosure may have had a negative effect on the growth of Halophila ovalis, although this could not be confirmed without replication. This species displayed a summer peak in abundance in the unprotected plot, but not in the adjacent exclosure (Fig. 6). This response may have been due to shading by drift algae that accumulated on the exclosure ropes. 


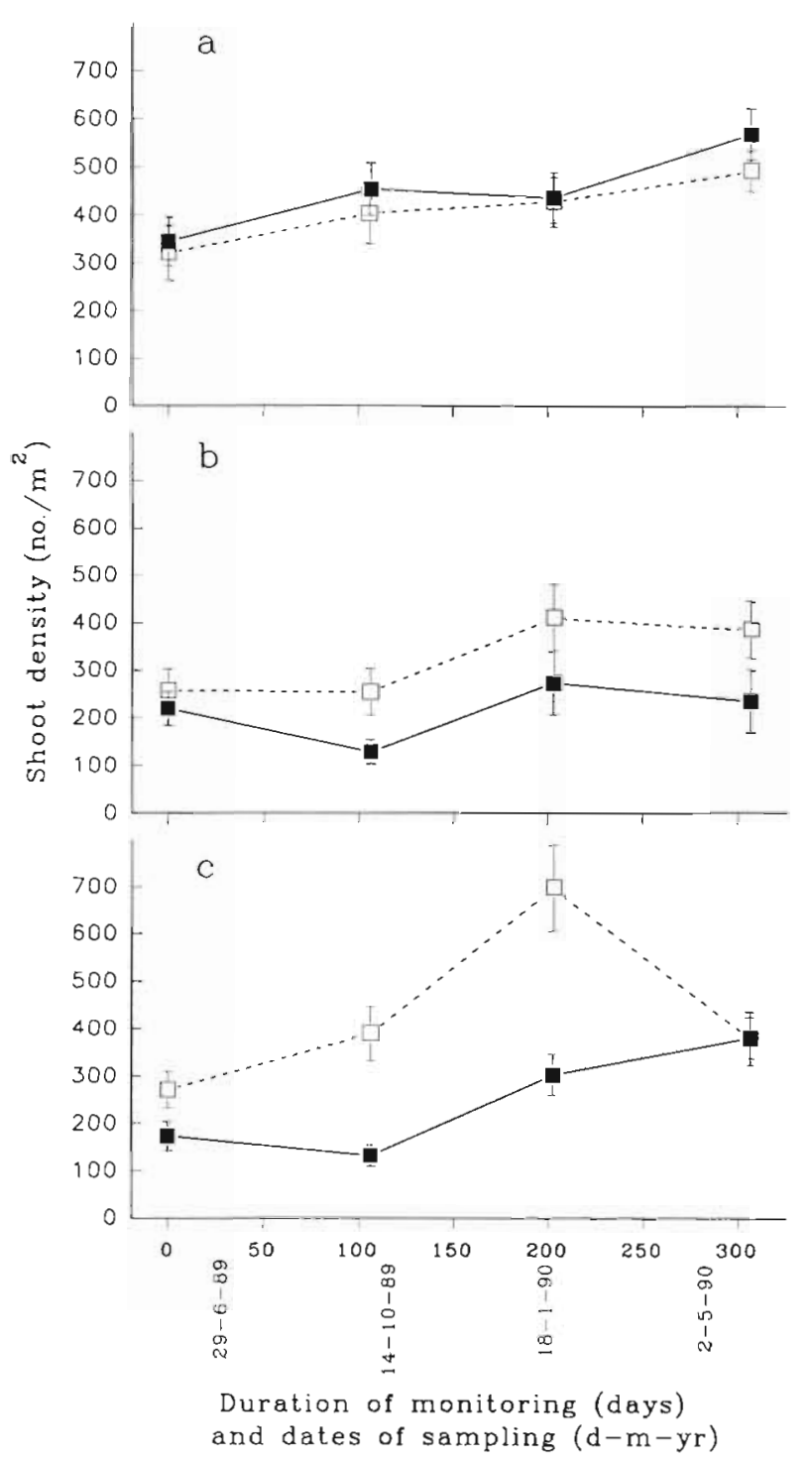

Fig. 6. Shoot density (mean $\pm \mathrm{SE}$ ) of seagrasses in the exclosure and the adjacent $(\square)$ unprotected plot at the exclosure control site. (a) Zostera capricorni, (b) Halophila spinulosa, (c) Halophila ovalis

\section{Effects of grazing treatments}

As expected, there were significant effects of grazing level, time and grazing level $\times$ time (Table 2). The result of interest is the significant interaction between grazing level $\times$ species $\times$ time. To interpret this result, the means of each grazing level $\times$ species $\times$ time combination have been plotted, along with the critical values for Least Significant Difference comparisons (Fig. 7). Pretreatment shoot densities (for low- and high-intensity grazing treatments) have also been plotted, although these were not included in the analysis.

No-grazing treatment: In the absence of any grazing disturbance, the abundance of Zostera capricorni

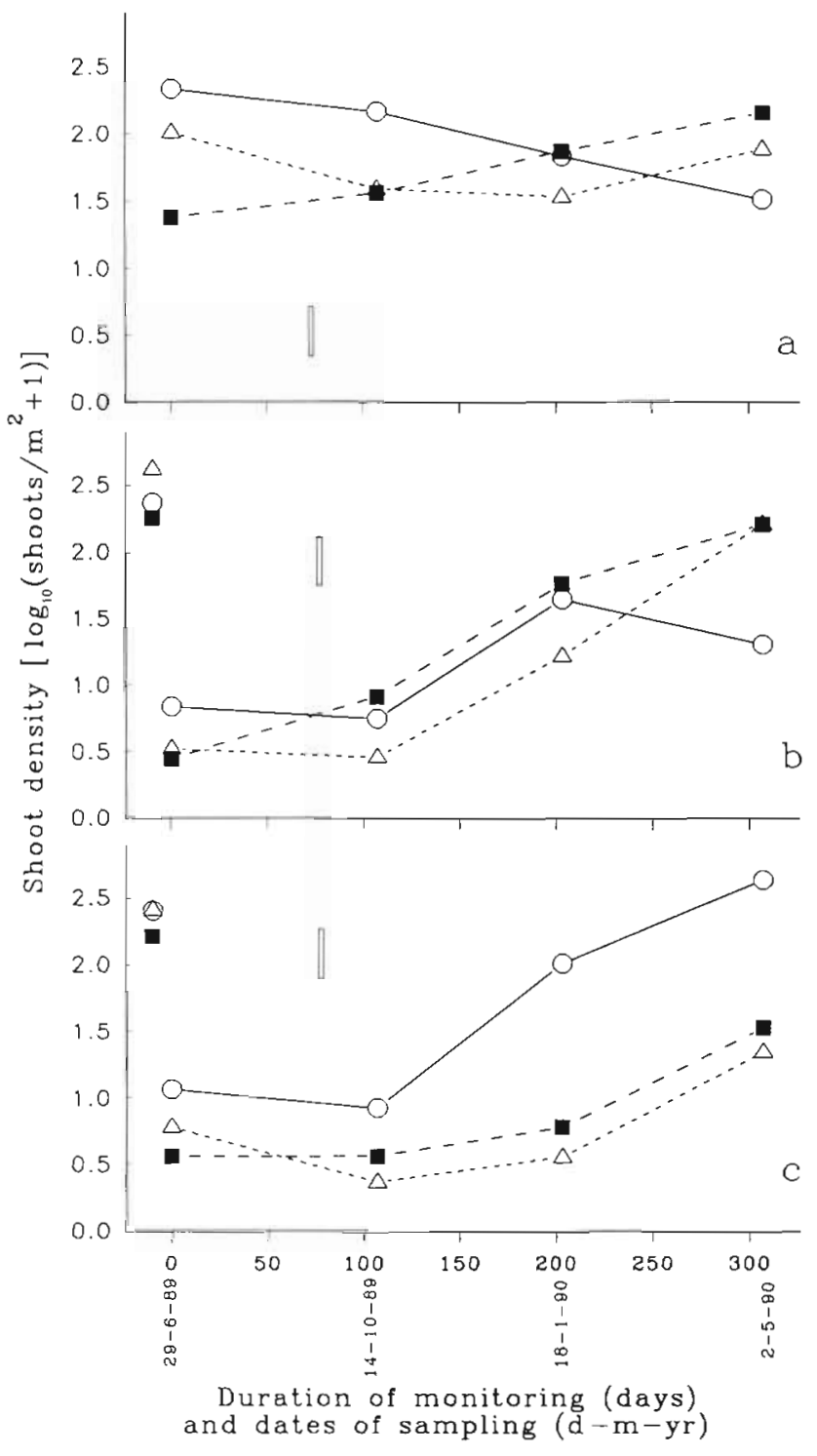

Fig. 7. Changes in shoot density of 3 species of seagrass under 3 treatments: (a) no grazing, (b) low-intensity grazing and (c) high-intensity grazing. Pretreatment shoot densities are shown on the left side of the graphs. Vertical bars: critical Least Significant Difference values for comparison between species within times. $(\Delta)$ Halophila spinulosa, (O) Halophila ovalis, ( $)$ Zostera capricorni

increased over the 10 mo monitoring period, while Halophila ovalis decreased (Fig. 7a). Z. capricorni was significantly less abundant than $H$. ovalis at the start of the experiment, but significantly more abundant at the end. The abundance of Halophila spinulosa showed no trend. These results indicate that $Z$. capricorni was not restricted physiologically at the experimental sites. The data also suggest that $H$. ovalis may eventually be competitively excluded from this seagrass community.

Low-intensity grazing: Averaged across species and sites, $89 \%$ of shoots were removed along the simulated 
Table 2. Results of analysis of variance of the exclosure experiment which examined the mean response of shoot density $\left[\log _{10}(\right.$ shoot density +1$\left.)\right]$ for each experimental plot at each of 4 times involving 3 species of seagrass under 3 regimes of simulated grazing by dugongs (no grazing, low-intensity and hrgh-intensity grazing)

\begin{tabular}{|c|c|c|c|c|c|}
\hline Factor & Error term & $d f$ & MS & $F$ & $\mathrm{p}$ \\
\hline Site & Site $\times$ Grz & 2 & 0.598 & 1.84 & 0.2507 \\
\hline Grazing level (Grz) & Site $\times$ Grz & 2 & 5.591 & 17.23 & 0.0108 \\
\hline Site $\times$ Grz & & 4 & 0.324 & & \\
\hline Time & Time $\times$ Site & 3 & 3.902 & 7.95 & 0.0164 \\
\hline Site $\times$ Time & & 6 & 0.491 & & \\
\hline Species & Species $\times$ Site & 2 & 1.366 & 0.94 & 0.4631 \\
\hline Site $\times$ Species & Site $\times$ Species $\times$ Grz & 4 & 1.455 & & \\
\hline Grz $\times$ Time & Grz $\times$ Time $\times$ Site & 6 & 1.161 & 26.61 & 0.0000 \\
\hline Site $\times$ Grz $\times$ Time & & 12 & 0.044 & & \\
\hline Grz $\times$ Species & Grz $\times$ Species $\times$ Site & 4 & 0.951 & 1.14 & 0.4049 \\
\hline Site $\times$ Grz $\times$ Species & & 8 & 0.836 & & \\
\hline Time $\times$ Species & Time $\times$ Species $\times$ Site & 6 & 0.413 & 2.23 & 0.1117 \\
\hline Site $\times$ Time $\times$ Species & & 12 & 0.185 & & \\
\hline Grz $\times$ Time $\times$ Species & Grz $\times$ Time $\times$ Species $\times$ Site & 12 & 0.337 & 6.75 & $0.000 t$ \\
\hline Site $\times$ Grz $\times$ Time $\times$ Species & & 24 & 0.050 & & \\
\hline
\end{tabular}

feeding trails (range: 78.5 to $99.2 \%$ ). This reduction is in accord with the level of shoot removal from real feeding trails (72 to $99 \%$; Preen 1993).

The seagrasses recolonised the 'feeding trails' primarily through ingrowth from the edges. The first $100 \mathrm{~d}$ of the experiment corresponded with winter and spring. Consequently, Zostera capricorni, which uniquely has a winter-spring growth period in Moreton Bay (Preen 1993), colonised the 'feeding trails' first (Fig. 7b). By the end of the experiment, Z. capricorni and Halophila spinulosa had recovered to pretreatment levels. Halophila ovalis, however, was significantly less abundant (Fig. 7 b). These results suggest that within the seagrass community tested, disturbance from low-intensity grazing by dugongs does not alter the relative abundance of $Z$. Capricorni and $H$. spinulosa, and may even reduce the relative abundance of $H$. ovalis.

High-intensity grazing: On average, $83 \%$ of seagrass shoots were removed from the plots designed to simulate intensive grazing by dugongs (range: 69.4 to $94.4 \%$ ). This compares with reductions of 87 , 65,95 and $92 \%$ at grazing Areas 1, 2, 3-1 and 3-2 (Table 1).

Recovery of the seagrass within this treatment resulted from the expansion of surviving plants and possibly from seed germination. The winter-spring period at the start of the experiment retarded any recovery for the first 100 d. Halophila ovalis showed significantly greater recovery than Zostera capricorni or Halophila spinulosa, increasing its relative and absolute abundance particularly during the 100 to $200 \mathrm{~d}$ period (Fig. 7c). These data support the hypothesis that disturbance, such as that caused by the sustained grazing of a large herd of dugongs, is capable of altering the mix of species in a seagrass meadow for a period of at least 10 mo. Fast growing species such as $H$. ovalis are apparently advantaged over high biomass species such as $Z$. capricorni.

\section{DISCUSSION}

Grazing by dugongs can constitute a major disturbance to seagrass meadows. At favoured locations, the intersecting feeding trails can cover virtually the entire substrate over large areas. At 1 site in Moreton Bay (Area 3; 41 ha) the density of seagrass shoots was reduced by $95 \%$ when it was first grazed and by $92 \%$ 6 mo later, when the partly recovered site was grazed again. On the second grazing the aboveground biomass was reduced by $96 \%$, while $71 \%$ of the belowground biomass was removed. This impact is of a similar scale to that of some terrestrial herbivores. For example, large herds (over half a million) of wildebeest Connochaetes taurinus albojubatus remove $85 \%$ of green biomass as they migrate through areas (McNaughton 1976). The disturbance caused by dugong grazing differs from that of most terrestrial herbivores, however, because a substantial proportion of the belowground plant material is also consumed

\section{Recovery}

Despite the intensity, areal extent and subsurface impact of grazing by dugong herds, the recovery of the seagrasses can be rapid (Figs. $3 \& 4$ ). This recovery is facilitated by the way dugongs feed, as well as by the growth characteristics of seagrasses. Rather than each 
dugong methodically cropping all the seagrass in a series of adjoining small areas, the dugongs feed along linear, meandering feeding trails that are about as wide as their muzzles. Despite the great density of these overlapping and intersecting trails, small tufts of seagrass survive (Fig. 1c). These represent an ungrazable reserve (Noy-Meir 1975), and are the key to the resilience of the seagrass meadows in the face of intensive grazing disturbance. At Area 3 , the ungrazable reserve was about 110 to 120 shoots $\mathrm{m}^{-2}$ (about $4 \%$ of pregrazing density). These shoots, aggregated in small tufts, sometimes linked by surviving rhizomes, act as nuclei able to expand to fill the bare gaps once grazing ceases. This regrowth is facilitated by the vegetative morphology of seagrasses, as the fragmentation of the rhizomes by feeding trails allows determinate shoots to be converted to indeterminate shoots, thus promoting proliferative growth (Tomlinson 1974).

The recovery of seagrass from grazing disturbance contrasts with recovery from disturbances caused by sedimentation, water or ice scour or some forms of dieoff (Short 1983, Poiner et al. 1989). The critical difference is the effective patch size: the minimum distance between survivors capable of regeneration (Connell \& Keough 1985). Hence, while an area of $>50$ ha may be severely disturbed by dugong grazing, the effective patch size is less than $1 \mathrm{~m}^{2}$, so recovery can be rapid. Areas of seagrass meadows affected by sedimentation or die off are often uniformly impacted and must recover by ingrowth from the edges, or by colonisation by seeds or other propagules. Under these circumstances recovery can take years (Birch \& Birch 1984, Clarke \& Kirkman 1989, Poiner et al. 1989, Preen et al. in press).

Recovery of heavily grazed seagrass meadows, however, is not invariably rapid. After the initial grazing of Area 3, no dugongs were seen at the site for $5 \mathrm{mo}$, and recovery was fast, despite the unfavourable growing season (winter). However, following the second grazing incident at this site, the recovery of the seagrass was suppressed by continued low-intensity grazing (Fig. 4), despite the favourable growing season.

\section{Effect of grazing disturbance on species composition}

The exclosure experiments showed that a disturbance, like intensive dugong grazing, can alter the relative abundance of seagrasses. Disturbance of a mixed species community encouraged Halophila ovalis, a pioneer species (Brouns 1987), while it retarded the expansion of Halophila spinulosa and Zostera capricorni, which is the dominant species in Moreton Bay. Such disturbance may be important in preventing $Z$. capricorni from dominating most seagrass habitats in the study area. In Moreton Bay, Z. capricorni is the dugongs' least preferred species, while $H$. ovalis and Halodule uninervis (thin-leafed morph) are their most preferred, followed by $H$. spinulosa (assessment based on the frequency of occurrence of dugongs on seagrass communities; selective feeding within seagrass communities; and active avoidance of $Z$. capricorni patches; Preen 1993). Of all the seagrasses in Moreton Bay, $Z$. capricorni is the most fibrous, while $H$. ovalis is the least fibrous and contains the highest levels of nitrogen (Lanyon 1991)

At grazing Area 4 , the changes in the relative abundance of the seagrasses reflected the pattern seen in the exclosure experiment that simulated intensive grazing. While Zostera capricorni was abundant at this site prior to the presumed grazing, 2 yг of data indicate that recovery to that successional stage would take at least 3 yr. In the meantime, Halophila ovalis dominated the site 9 to 12 mo after grazing, followed by the dominance of Halophila spinulosa, 18 to more than 21 mo after the grazing (Fig. 5). Thus the dugong's preferred species of seagrasses are favoured by intensive grazing, at the expense of less preferred species.

No changes in species composition were detected following disturbance by grazing at Areas 2 and 3 . These sites were virtually pure stands of Halophila ovalis (Area 3) or Halodule uninervis (Area 2), both species that are adapted to disturbance (Birch \& Birch 1984, Brouns 1987).

Heavy grazing pressure in terrestrial grasslands frequently converts pastures to a lower seral stage, composed of less palatable, grazing resistant species, resulting in a lower carrying capacity (Willms et al. 1988, Edroma 1989, Ralphs et al. 1990). This contrasts with the seagrasses in Moreton Bay, where heavy grazing pressure converts the meadows to a lower seral stage, dominated by a more palatable, grazingtolerant species, probably resulting in a higher carrying capacity (see below).

\section{Effect of grazing disturbance on forage quality}

The nutritional quality of plants can increase following injury, including damage caused by herbivory (Karban \& Myers 1989). The shoot nitrogen concentration of terrestrial plants (Kilcher 1981, Coppock et al. 1983) and seagrasses (Harrison \& Mann 1975, Zieman et al. 1984) generally declines as the plants age and mature. However, in grasses, heavy or prolonged grazing often increases the shoot nitrogen content (Bakker et al. 1983, Coppock et al. 1983. McNaughton 1984. Jaramillo \& Detling 1988, Heitschmidt et al. 1989). Seagrasses respond to cropping or clipping of leaves by increasing nitrogen levels and decreasing levels of 
lignin or ash in new growth (Dawes \& Lawrence 1979, Bjorndal 1980, Thayer et al. 1984, Zieman et al. 1984). Thus, concentrated grazing may allow dugongs to maximise the quality of their diet not only by increasing the area of nutritionally superior, early successional species of seagrass, but by increasing the nutritional quality of grazed seagrasses generally. This is achieved by maintaining meadows in an immature, rapidly growing state. Green turtles Chelonia mydas maintain seagrass patches in this growth stage (Bjorndal 1980, Ogden et al. 1980, Thayer et al. 1984, Zieman et al. 1984), as do some large terrestrial herbivores (McNaughton 1985, Edroma 1989).

\section{Why feed in large herds?}

McNaughton (1984) argues that the modification of the vegetation physiognomy is the most important impact of grazing ungulates. By reducing the grass canopy height and increasing tillage, the green biomass is concentrated closer to the ground, and the grazers increase their food-yield per bite, which can be critical to meeting the nutritional needs of large mammalian herbivores under some circumstances (Stobbs 1973, Chacon et al. 1978). Grazing by dugongs does not directly increase the food per bite, or food per dive, as the intense grazing tends to lower the biomass of seagrass. However, by disturbing large areas at a time and thus encouraging uniform recovery of favoured species, intensive, herd-based grazing achieves the equivalent of McNaughton's (1984) biomass concentration.

McNaughton (1984) further postulates that gregariousness in grazing animals may have evolved because of the increase in foraging efficiency that accrues to individuals as a result of changes in vegetation structure that follow herd grazing. He argues that while lone animals could achieve the same increase in forage-yield per bite, by concentrating their grazing in a small area, such animals would be highly subject to predation. Predation, however, has not prevented green turtles (Bjorndal 1980, Ogden et al. 1980, Thayer et al. 1984, Zieman et al. 1984) and damselfish (Sammarco 1983, Kamura \& Choonhabandit 1986, Hinds \& Ballantine 1987) from maintaining individual foraging patches of seagrass and algae, respectively. Solitary dugongs are prevented from farming seagrasses, not by predation, but by their mode of feeding. They feed as they swim forward, removing seagrass from long, muzzle-wide strips. For an individual dugong to efficiently disturb a substantial single area of seagrass it would have to feed along adjoining, very narrow strips. The characteristic meandering path of most feeding trails suggests that such control would be diffi- cult to achieve. Hence, it is unlikely that individuals could change the species composition of the seagrass bed and concentrate the regrowth into distinct patches so that it could be efficiently harvested. Only by feeding in large herds, so the overlap of many meandering feeding trails results in a high intensity of disturbance over a large area, can dugongs achieve these results.

\section{Cultivation grazing}

The grazing pattern described for dugongs in Moreton Bay has profound impacts on seagrass communities. By feeding in large herds, for sustained periods, the dugongs significantly disturb large areas of seagrass. From the dugong's perspective, the subsequent changes to the seagrasses are beneficial. The nutritional quality of the regenerating seagrasses is higher than before grazing (more nitrogen, less fibre), and the improved scagrass resource is concentrated in a manner that can be harvested by the dugongs. In mixedspecies communities, the abundance and concentration of nutritionally superior, early pioneer species is increased, while the expansion of the dominant, but least preferred seagrass Zostera capricorni into feeding areas is stalled. This grazing pattern, which may be termed cultivation grazing, is likely to be an important foraging strategy of dugongs.

Acknowledgements. Logistical support was provided by CSIRO Fisheries Laboratory, Cleveland. I. Poiner provided suggestions on the design of the exclosure experiment. G. De'ath assisted greatly with statistical analyses. $T$ O'Shea and $H$. Marsh provided very valuable comments on an earlier draft.

\section{LITERATURE CITED}

Bakker JP, de Leeuw J, van Wieren SE (1983) Micro-patterns in grassland vegetation created and sustained by sheepgrazing. Vegetatio 55:153-161

Birch WR (1975) Some chemical and calorific properties of tropical marine angiosperms compared with those of other plants. J appl Ecol 12:201-212

Birch WR, Birch M (1984) Succession and pattern of tropical intertidal seagrasses in Cockle Bay, Queensland, Australia: a decade of observations. Aquat Bot 19:343-367

Bjorndal KA (1980) Nutrition and grazing behaviour of the green turtle Chelonia mydas. Mar Biol 56:147-154

Brouns JJWM (1987) Growth patterns in sorne Indo-WestPacific seagrasses. Aquat Bot 28:39-61

Chacon EA, Stobbs TH, Dale MB (1978) Influence of sward characteristics on grazing behaviour of cattle. Aust J agnc Res 29:89-102

Clark SM, Kirkman H (1989) Seagrass dynamics. In: Larkum AWD, McComb AJ, Shepherd SA (eds) Biology of seagrasses. A treatise on the biology of seagrasses with special reference to the Australian region. Elsevier, Amsterdam, p 304-335 
Connell $\mathrm{JH}_{4}$, Keough MJ (1985) Disturbance and patch dynamics of subtidal marine animals on hard substrata. In: Pickett STA, White PS (eds) The ecology of natural disturbances and patch dynamics. Academic Press, New York, p 125-152

Coppock DL, Detling JK, Ellis JE, Dyer MI (1983) Plantherbivore interactions in a north American mixed-grass prairie. I. Effects of black-tailed prairie dogs on intrasexual aboveground plant biomass and nutrient dynamics and plant species diversity. Oecologia 56:1-9

Dawes CJ, Lawrence JM (1979) Effects of blade removal on the proximate composition of the rhizome of the seagrass Thalassia testudinum Banks ex Konig. Aquat Bot 7:255-266

Duarte CM (1990) Seagrass nutrient content. Mar Ecol Prog Ser 67:201-207

Edroma EL (1989) The response of tropical vegetation to grazing and browsing in Queen Elizabeth National Park. Uganda. In: Jewell PA, Maloiy GMO (eds) The biology of large African mammals in their environment. Symp zool Soc Lond 61:1-13

Harrison PG, Mann KH (1975) Chemical changes during the seasonal cycle of growth and decay in eelgrass (Zostera marina) on the Atlantic coast of Canada. J Fish Res Bd Can 32:615-621

Heitschmidt RK, Dowhower SL, Pinchak WE, Canon SK (1989) Effects of stocking rate on quantity and quality of available forage in a southern mixed grass prairie. J Range Manag 42:468-473

Hinds PA, Ballantine DL (1987) Effects of the Caribbean threespot damselfish, Stegastes planifrons (Cuvier), on algal lawn composition. Aquat Bot 27:299-308

Jaramillo VJ, Detling JK (1988) Grazing history, defoliation, and competition: effects on shortgrass production and nitrogen accumulation. Ecology 69:1599-1608

Johnstone I, Hudson BET (1981) The dugong diet: mouth sample analysis. Bull mar Sci 31:681-690

Kamura S, Choonhabandit S (1986) Algal communities withm territories of the damselfish Stegastes apicalis and the effects of grazing by the sea urchin Diadema spp. in the Gulf of Thailand. Galaxea 5:175-193

Karban R, Myers JH (1989) Induced plant responses to herbivory. A Rev Ecol Syst 20:331-348

Kenworthy WJ, Thayer GW (1984) Production and decomposition of the roots and rhizomes of seagrasses, Zostera marina and Thalassia testudinum, in temperate and sub. tropical marine ecosystems. Bull mar Sci 35:364-379

Kilcher MR (1981) Plant development, stage of maturity and nutrient composition. J Range Manag 34:363-364

Lanyon $J$ (1991) The nutritional ecology of the dugong (Dugong dugon) in tropical north Queensland. PhD thesis, Monash University, Australia

Lipkin Y (1975) Food of the Red Sea Dugong (Mammalia Sirenia) from Sinai. Isr J Zool 24:81-98

Leuthold W (1977) African ungulates. A comparative review of their ethology and behavioural ecology. SpringerVerlag, Berlin

Marsh H, Chanells PW, Heinsohn GE, Morrissey J (1982) Analysis of stomach contents of dugongs from Queens. land. Aust Wildl Res 9:55-67

Mattson WJ (1980) Herbivory in relation to plant nitrogen. A Rev Ecol Syst 11:119-161.

This article was submitted to the editor
McNaughton SJ (1976) Serengeti migratory wildebeest: facilitation of energy flow by grazing. Science 191:92-94

McNaughton SJ (1984) Grazing lawns: animals in herds, plant form, and coevolution. Am Nat 124:863-886

McNaughton SJ (1985) Ecology of a grazing ecosystem: the Serengeti. Ecol Monogr 55:259-294

Noy Meir I (1975) Stability of grazing systems: an application of predator-prey graphs. J Ecol 63(2):459-481

Ogden JC, Tighe S, Miller S (1980) Grazing of seagrass by large herbivores in the caribbean. Am Zool 20:949

Poiner IR, Walker DI, Coles RG (1989) Regional studies seagrasses of tropical Australia. In: Larkum AWD. McComb AJ, Shepherd SA (eds) Biology of seagrasses. A treatise on the biology of seagrasses with special reference to the Australian region. Elsevier, Amsterdam, p 279-303

Preen AR (1993) lnteractions between dugongs and seagrasses in a subtropical environment. PhD thesis, James Cook University of North Queensland

Preen AR (1995) Diet of dugongs: are they omnivores? J Mammal 76:163-171

Preen AR, Lee Long WJ, Coles RG (in press) Flood and cyclone related loss, and partial recovery, of more than $1,000 \mathrm{~km}^{2}$ of seagrass in Hervey Bay, Queensland, Australia. Aquat Bot

Ralphs $\mathrm{MH}$, Kothmann MM, Taylor CA (1990) Vegetation response to increased stocking rates in short duration grazing. J Range Manag 43:104-108

Sammarco PW (1983) Effects of fish grazing and damselfish territoriality on coral reef algae. l. Algal community structure. Mar Ecol Prog Ser 13:1-14

SAS Institute Inc (1991) SAS system for linear models, 3rd edn. SAS Institute Inc, Cary, NC

Short FT (1983) The response of interstitial ammonium in eelgrass (Zostera marina L.) beds to environmental perturbations. J exp mar Biol Ecol 68:195-208

Sinclair ARE (1977) The Afncan buffalo. A study of resource limitation of populations. University of Chicago Press, Chicago

Spain AV, Heinsohn GE (1975) Size and weight allometry in a north Queensland population of Dugong dugon (Müller) (Mammalia: Sirenia). Aust J Zool 23:159-168

Stobbs TH (1973) The effect of plant structure on the intake of tropical pastures II. Differences in sward structure, nutritive value, and bite size of animals grazing Setaria anceps and Chloris gayana at various stages of growth. Aust J agric Res 24:821-829

Thayer GW, Bjorndal KA, Ogden JC, Williams SL, Zieman JC (1984) Role of larger herbivores in seagrass communities. Estuaries 7:351-376

Tomlinson PB (1974) Vegetative morphology and meristem dependence - the foundation of productivity in seagrasses. Aquaculture 4:107-130

White TCR (1993) The inadequate environment. Nitrogen and the abundance of animals. Springer-Verlag, Berlin

Willms WD, Dormaar JF Schaalje GB (1988) Stability of grazed patches on rough fescue grasslands. J Range Manag 41:503-508

Zieman JC, Iverson RL, Ogden JC (1984) Herbivory effects on Thalassia testudinum leaf growth and nitrogen content. Mar Ecol Prog Ser 15:151-158

Manuscript first received: September 1, 1994

Revised version accepted: March 14, 1995 